\title{
Mechanisms of different cultivars of Cucurbita pepo in resistance to Podosphaera xanthii infection through improvement of antioxidative defense system and gene expression
}

Shuwu Zhang

Gansu Agricultural University

Bingliang Xu ( $\sim$ xubl@gsau.edu.cn )

Gansu Agricultural University

Jia Liu

Gansu Agricultural University

Research article

Keywords: Cucurbita pepo, Powdery mildew, Podosphaera xanthii, Disease incidence and index, Reactive oxygen species (ROS), Phenylalanine ammonia-lyase (PAL), Antioxidative defense system, Gene expression

Posted Date: May 29th, 2020

DOI: https://doi.org/10.21203/rs.3.rs-29698/v1

License: (c) (i) This work is licensed under a Creative Commons Attribution 4.0 International License. Read Full License 


\section{Abstract}

Background: Powdery mildew is one of the world's most destructive diseases of cucurbit and the major cause of losses in its production worldwide. A number of strategies have been developed and applied to discover some suitable and alternative safe methods to manage the powdery mildew disease occurrence, but little information is regarding to screen of resistant pumpkins (Cucurbita pepo L.) germplasm and explore the mechanisms of their preventing the disease occurrence at physiological, biochemical, and molecular levels. Therefore, we evaluated and determined the ability and mechanisms of two commercial pumpkin cultivars in resistance to Podosphaera xanthii infection.

Results: Compared with mock-inoculated seedlings, small and sparse spots were observed on the cultivar of Sixing $F_{1}$ leaves at the $13^{\text {th }}$ day after inoculation with $P$. xanthii, whereas a large number of disease spots or a layer of white powdery mildew were observed on the surface of $\operatorname{Jin}_{12} F_{1}$ leaves. Increased the inoculation time (7, 9, 11 and 13 days) significantly and continuously increased the disease incidence and index of pumpkin seedlings after inoculation. The disease incidence and index of $\operatorname{Jin}_{12} F_{1}$ were significantly higher than the cultivar of Sixing $F_{1}$. At Day 13 , the disease incidence and index of $\operatorname{Jin}_{12} F_{1}$ were $80.0 \%$ and 72.6 , whereas the cultivar of Sixing $F_{1}$ was $22.3 \%$ and 17.7 , respectively. The contents of $\mathrm{H}_{2} \mathrm{O}_{2}, \mathrm{MDA}$, lignin and total phenolics in the leaves of Sixing $\mathrm{F}_{1}$ and $\mathrm{Jin}_{12} \mathrm{~F}_{1}$ were markedly accelerated after inoculation with $P$. xanthii. However, the cultivar of Sixing $F_{1}$ exhibited less reactive oxygen species (ROS) accumulation, a lower rate of lipid peroxidation and higher level of lignin and total phenolics contents after inoculation, whereas the cultivar of $\operatorname{Jin}_{12} F_{1}$ exhibited higher level of ROS accumulation and rates of lipid peroxidation, and lower level of lignin and total phenolics contents. Higher activity and transcript level of antioxidant enzymes and gene of PAL expression were observed on different tissues of both cultivars after inoculated with $P$. xanthii. Compared with pumpkin seedlings that were inoculated with sterile water but not $P$. xanthii, the level of PAL activity and gene expression in leaves, petioles and stems of Sixing $F_{1}$ and $\operatorname{Jin}_{12} F_{1}$ were upregulated and increased significantly at different time points after inoculation. The enhancement expression of PAL activity and gene in different tissues of Sixing $F_{1}$ was significantly higher than $\operatorname{Jin}_{12} F_{1}$, and higher in leaves, lower in petioles and stems.

Conclusions: Our results indicate that the cultivar of Sixing $F_{1}$ exhibited the highest ability in resistance to $P$. xanthii infection in comparison to $\operatorname{Jin}_{12} \mathrm{~F}_{1}$, and one novel possible mechanism is related to the cultivars in resistance to $P$. xanthii infection by activating and enhancing the antioxidative defense system and gene expression to prevent the pathogens infection.

\section{Background}

Pumpkin (Cucurbita pepo L.) is one of the most important vegetable crops for human nutrition all over the world [1]. However, powdery mildew is a common and major disease of pumpkin that affects the seedlings and mature plants growth [2], and also is one of the limiting factors that causing severely economic losses in pumpkin by shortening the ripening and harvest intervals, reducing photosynthesis 
and yields, and decreasing fruit quality in field and greenhouse $[3,4]$. Normally, the pumpkin yield losses due to the disease of powdery mildew by 30 to 50\% [5]. In addition, Podosphaera xanthii has been considered as one of the most important pathogens that causing the disease of cucurbit powdery mildew and reducing the production worldwide [6]. Thus, suitable control measurements and alternative safe methods, such as effective and friendly environment control methods are needed to overcome these problems.

In past few years, some strategies have been adapted to manage the disease of powdery mildew in agriculture, including the use of chemical, biological fungicides and breeding the resistance varieties [7]. Similar study has reported that the application of fungicides is the most efficient method to control powdery mildew in Iran and elsewhere [8]. However, chemical fungicide that is not healthy and safe due to it hazardous effects on human, animals, plants, and beneficial organisms, as well as developing pathogen resistance [9]. Although biological control agents have been applied to control of powdery mildew, their efficacy mainly depends on climatic conditions [10]. Therefore, screening of resistant pumpkin germplasm will be the best way for developing new cultivars to prevent the disease of powdery mildew occurrence. The resistance to powdery mildew was first observed in cucumber (Cucumis sativus L. cv. Puerto Rico 37) [11], thereafter, a large number of resistant materials were found in local cucurbit varieties from South and East Asia [12], but little is known about the specific knowledge for discovering and developing new resistant varieties of pumpkin to prevent powdery mildew occurrence in China, and the mechanisms of pumpkin in resistance to $P$. xanthii infection is a very complex phenomenon and the nature remains unresolved.

A number of studies have been demonstrated that plants can develop appropriate defense mechanisms to recognize and resist inevitable pathogen attacks, i.e. plants defend themselves against fungal infection through the activation of complex defense responses [13]. One of the earliest these responses is the rapid generation of reactive oxygen species (ROS), which includes superoxide anion $\left(\mathrm{O}^{2-}\right)$, hydroxyl radical $\left(\mathrm{OH}^{-}\right)$ and hydrogen peroxide $\left(\mathrm{H}_{2} \mathrm{O}_{2}\right)$ [14]. Meanwhile, phenylpropanoid pathway is another most important secondary metabolism pathways and defense responses in higher plants $[15,16]$. Phenylalanine ammonia-lyase (PAL) is the first enzyme in the phenylpropanoid pathway, participating in the formation of a series of structural and defensive lignin and phenolic compounds [17-20]. Furthermore, PAL gene has been widely studied in participating in plant growth, development and defense systems [21-23], such as the upregulated expression of PAL gene in plants that can help plant to develop resistance to phytopathogens infection [24-26]. However, to our knowledge, there is little published information regarding the mechanisms of different cultivars of $C$. pepo in resistance to $P$. xanthii infection at physiological, biochemical, and molecular levels.

In view of the above background, the aims of our present study were to (i) evaluate the ability and effectiveness of two commercial pumpkin cultivars in resistance to $P$. xanthii infection, and (ii) determine the defense responses pathway in two commercial pumpkin cultivars after inoculated with the pathogen of $P$. xanthii at different time points, and (iii) explore the possible mechanisms involved in two different pumpkin cultivars in response to $P$. xanthii infection at physiological, biochemical, and molecular levels. 


\section{Results}

\section{Symptoms of Cucurbita pepo after inoculation with Podosphaera xanthii}

Compared with mock-inoculated $\operatorname{Jin}_{12} F_{1}$ (Fig. 1C) and Sixing $F_{1}$ seedlings (Fig. 1D), small and sparse spots were observed on the cultivar of Sixing $\mathrm{F}_{1}$ leaves at the $13^{\text {th }}$ day after inoculation with $P$. xanthii (Fig. 1B), whereas a large number of disease spots were observed on the surface of $\operatorname{Jin}_{12} F_{1}$ leaves, even a layer of white powdery mildew was covered on the leaves (Fig. 1A) in comparison to the mockinoculated $\operatorname{Jin}_{12} F_{1}$ seedlings (Fig. 1C). However, the cultivars of $\operatorname{Jin}_{12} F_{1}$ (Fig. 1C) and Sixing $F_{1}$ (Fig. 1D) leaves have no disease spots occurred in the control group.

\section{Disease severity of Cucurbita pepo after inoculation with Podosphaera xanthii}

Compared with pumpkin leaves that were inoculated with sterile water but not $P$. xanthii, the cultivars of $\operatorname{Jin}_{12} \mathrm{~F}_{1}$ and Sixing $\mathrm{F}_{1}$ were begun to show the disease symptoms after inoculated with the pathogen of $P$. $x a n t h i i$ at the $5^{\text {th }}$ and $7^{\text {th }}$ days, respectively. However, the disease incidence and index were significantly different between the cultivars of Sixing $F_{1}$ and $\operatorname{Jin}_{12} F_{1}$ after inoculation with $P$. xanthii. In contrast, the mock-inoculated seedlings of Sixing $F_{1}$ and $\operatorname{Jin}_{12} F_{1}$ were grown normally, and have no disease symptoms at the recorded days after inoculation, respectively.

Increased the inoculation time (7, 9, 11 and 13 days) significantly and continuously increased the disease incidence and index of two cultivars pumpkin seedlings. The disease incidence and index of $\operatorname{Jin}_{12} \mathrm{~F}_{1}$ were significantly higher than the cultivar of Sixing $F_{1}$. At Day 13 , the disease incidence and index of $\operatorname{Jin}_{12} F_{1}$ were $80.0 \%$ and 72.6 , respectively, whereas the cultivar of Sixing $F_{1}$ was $22.3 \%$ and 17.7 , respectively.In addition, the cultivar of $\operatorname{Jin}_{12} F_{1}$ began to show symptoms at the $5^{\text {th }}$ day after inoculation, while the cultivar of Sixing $F_{1}$ at the $7^{\text {th }}$ day after inoculation. Furthermore, the speed of disease spots expansion of the cultivar $\operatorname{Jin}_{12} F_{1}$ was faster than Sixing $F_{1}$ with the increase of inoculation time (Table 1 and Table 2). 
Table 1

The disease incidence of different cultivars of Cucurbita pepo after inoculation with Podosphaera xanthii

\section{Cultivars Treatments Days post inoculation (dpi)}

\begin{tabular}{|c|c|c|c|c|c|c|c|c|}
\hline & & 1 & 3 & 5 & 7 & 9 & 11 & 13 \\
\hline & & - & - - - & ease in & ence $(\%$ & -_- & & \\
\hline \multirow[t]{2}{*}{ Sixing $F_{1}$} & Treatment & $0.0 \mathrm{a}$ & $0.0 \mathrm{a}$ & $0.0 \mathrm{~b}$ & $6.7 \mathrm{~b}$ & $16.7 \mathrm{~b}$ & $21.3 b$ & $22.3 \mathrm{~b}$ \\
\hline & Control & $0.0 \mathrm{a}$ & $0.0 \mathrm{a}$ & $0.0 \mathrm{~b}$ & $0.0 \mathrm{c}$ & $0.0 \mathrm{c}$ & $0.0 \mathrm{c}$ & $0.0 \mathrm{c}$ \\
\hline \multirow[t]{2}{*}{$\operatorname{Jin}_{12} F_{1}$} & Treatment & $0.0 \mathrm{a}$ & $0.0 \mathrm{a}$ & $3.3 \mathrm{a}$ & $26.7 \mathrm{a}$ & $60.0 \mathrm{a}$ & $76.7 \mathrm{a}$ & $80.0 \mathrm{a}$ \\
\hline & Control & $0.0 \mathrm{a}$ & $0.0 \mathrm{a}$ & $0.0 \mathrm{~b}$ & $0.0 \mathrm{c}$ & $0.0 \mathrm{c}$ & $0.0 \mathrm{c}$ & $0.0 \mathrm{c}$ \\
\hline
\end{tabular}

Data are means of twelve replicates. Different letters in the same column denote significant differences at the $p<0.05$ level by Duncan's new multiple range test $(n=12)$. In the two treatments, pumpkin seedlings leaves were inoculated with $P$. xanthii, whereas in the two controls, pumpkin seedlings leaves were inoculated with sterile water but not $P$. xanthii

Table2

The disease index of different cultivars of Cucurbita pepo after inoculation with Podosphaera xanthii

\section{Cultivars Treatments Days post inoculation (dpi)}

\begin{tabular}{|c|c|c|c|c|c|c|c|c|}
\hline & & 1 & 3 & 5 & 7 & 9 & 11 & 13 \\
\hline & & - & - - - & isease & $e x-$ & - & & \\
\hline \multirow[t]{2}{*}{ Sixing $F_{1}$} & Treatment & $0.0 \mathrm{a}$ & $0.0 \mathrm{a}$ & $0.0 \mathrm{~b}$ & $4.7 \mathrm{~b}$ & $13.3 \mathrm{~b}$ & $16.4 \mathrm{~b}$ & $17.7 \mathrm{~b}$ \\
\hline & Control & $0.0 \mathrm{a}$ & $0.0 \mathrm{a}$ & $0.0 \mathrm{~b}$ & $0.0 \mathrm{c}$ & $0.0 \mathrm{c}$ & $0.0 \mathrm{c}$ & $0.0 \mathrm{c}$ \\
\hline \multirow[t]{2}{*}{$\operatorname{Jin}_{12} F_{1}$} & Treatment & $0.0 \mathrm{a}$ & $0.0 \mathrm{a}$ & $3.3 \mathrm{a}$ & $16.7 a$ & $40.7 \mathrm{a}$ & $46.0 \mathrm{a}$ & $72.6 \mathrm{a}$ \\
\hline & Control & $0.0 \mathrm{a}$ & $0.0 \mathrm{a}$ & $0.0 \mathrm{~b}$ & $0.0 \mathrm{c}$ & $0.0 \mathrm{c}$ & $0.0 \mathrm{c}$ & $0.0 \mathrm{c}$ \\
\hline
\end{tabular}

Data are means of twelve replicates. Different letters in the same column denote significant differences at the $p<0.05$ level by Duncan's new multiple range test $(n=12)$. The treatments are detailed in the footnote of Table 1

\section{Hydrogen peroxide $\left(\mathrm{H}_{2} \mathrm{O}_{2}\right)$ and lipid peroxidation (MDA) contents in pumpkin seedling}

The $\mathrm{H}_{2} \mathrm{O}_{2}$ and MDA contents of Sixing $\mathrm{F}_{1}$ and $\operatorname{Jin}_{12} \mathrm{~F}_{1}$ seedling leaves after inoculated with $P$. xanthii were increased with the increase of days post inoculation from 1 to 9 or 11 days, peaked at the $9^{\text {th }}$ and $11^{\text {th }}$ days, and then declined gradually. The $\mathrm{H}_{2} \mathrm{O}_{2}$ and MDA contents of $\operatorname{Jin}_{12} \mathrm{~F}_{1}$ were significantly higher 
than Sixing $\mathrm{F}_{1}$ with the increase of days post inoculation. The maximum $\mathrm{H}_{2} \mathrm{O}_{2}$ and MDA contents of Sixing $F_{1}$ were increased significantly by $26.83 \%$ and $26.42 \%$ at the $9^{\text {th }}$ and $11^{\text {th }}$ days after inoculation, respectively, whereas $27.08 \%$ and $28.32 \%$ increased in $\operatorname{Jin}_{12} F_{1}$ seedling leaves, compared with each of control under sterile water treatment, respectively (Table 3 ).

Table 3

$\mathrm{H}_{2} \mathrm{O}_{2}$ and MDA content in different cultivars of Cucurbita pepo seedlings after inoculation with Podosphaera xanthii

\begin{tabular}{|c|c|c|c|c|c|c|c|c|}
\hline \multirow[t]{2}{*}{ Cultivars } & \multirow[t]{2}{*}{ Treatments } & \multicolumn{7}{|c|}{ Days post inoculation (dpi) } \\
\hline & & 1 & 3 & 5 & 7 & 9 & 11 & 13 \\
\hline & -_-1_-1 & $\mathrm{O}_{2}(\mu \mathrm{mo}$ & $\left.-^{-1} \mathrm{FW}\right)$ & & - & & & \\
\hline \multirow[t]{2}{*}{ Sixing $F_{1}$} & Treatment & $0.25 \mathrm{c}$ & $0.28 \mathrm{~b}$ & $0.39 a$ & $0.46 \mathrm{~b}$ & $0.52 \mathrm{~b}$ & $0.47 b$ & $0.38 \mathrm{c}$ \\
\hline & Control & $0.23 \mathrm{~d}$ & $0.25 \mathrm{c}$ & $0.32 \mathrm{c}$ & $0.37 d$ & $0.41 \mathrm{~d}$ & $0.43 c$ & $0.35 \mathrm{~d}$ \\
\hline \multirow[t]{2}{*}{$\operatorname{Jin}_{12} F_{1}$} & Treatment & $0.29 \mathrm{a}$ & $0.31 \mathrm{a}$ & $0.37 b$ & $0.48 \mathrm{a}$ & $0.61 \mathrm{a}$ & $0.58 \mathrm{a}$ & $0.49 a$ \\
\hline & Control & $0.27 \mathrm{~b}$ & $0.28 \mathrm{~b}$ & $0.32 \mathrm{c}$ & $0.41 \mathrm{c}$ & $0.48 \mathrm{c}$ & $0.48 b$ & $0.44 b$ \\
\hline & \multicolumn{8}{|c|}{ 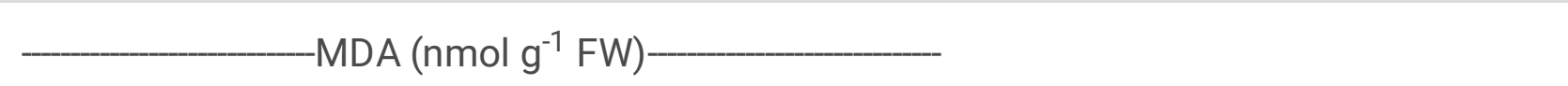 } \\
\hline \multirow[t]{2}{*}{ Sixing $F_{1}$} & Treatment & $2.45 \mathrm{c}$ & $2.91 \mathrm{~b}$ & $3.45 b$ & $4.05 \mathrm{c}$ & $4.61 \mathrm{c}$ & $4.69 \mathrm{c}$ & $4.35 \mathrm{c}$ \\
\hline & Control & $2.21 \mathrm{~d}$ & $2.45 \mathrm{c}$ & $2.88 \mathrm{c}$ & $3.27 d$ & $3.68 d$ & $3.71 \mathrm{~d}$ & $3.57 d$ \\
\hline \multirow[t]{2}{*}{$\operatorname{Jin}_{12} F_{1}$} & Treatment & $2.87 \mathrm{a}$ & $3.35 a$ & $3.68 \mathrm{a}$ & $5.07 \mathrm{a}$ & $5.31 \mathrm{a}$ & $6.66 \mathrm{a}$ & $5.98 a$ \\
\hline & Control & $2.64 \mathrm{~b}$ & $2.85 \mathrm{~b}$ & $3.56 \mathrm{~b}$ & $4.68 \mathrm{~b}$ & $5.08 \mathrm{~b}$ & $5.19 b$ & $4.94 \mathrm{~b}$ \\
\hline $\begin{array}{l}\text { Data are me } \\
\text { differences } \\
\text { detailed in th }\end{array}$ & $\begin{array}{l}\text { of twelve } \\
\text { he } p<0.05 \\
\text { ootnote of }\end{array}$ & $\begin{array}{l}\text { icates } \\
\text { el by } D \\
\text { ble } 1\end{array}$ & $\begin{array}{l}\text { ferent } \\
\text { an's } n\end{array}$ & $\begin{array}{l}\text { ters in the } \\
\text { multiple ra }\end{array}$ & $\begin{array}{l}\text { me col } \\
\text { ge test }\end{array}$ & $\begin{array}{l}\text { In denote } \\
\text { 12). The }\end{array}$ & $\begin{array}{l}\text { ificant } \\
\text { ments a }\end{array}$ & \\
\hline
\end{tabular}

\section{Levels of defense enzyme expression}

The activity of defense enzyme PAL in different cultivars and tissues of pumpkin (Sixing $F_{1}$ and $\operatorname{Jin}_{12} F_{1}$ ) was increased significantly at the $5^{\text {th }}$ day after inoculated with the pathogen of $P$. xanthii, peaked at the $7^{\text {th }}$ and $9^{\text {th }}$ days, and then declined gradually (Fig. 2 and Fig. 3). However, the activity of PAL differed significantly between the cultivars of Sixing $F_{1}$ and $\operatorname{Jin}_{12} F_{1}$. Higher level of PAL activity was expressed in the cultivar of Sixing $F_{1}$ leaves after inoculation in comparison to the $\operatorname{Jin}_{12} F_{1}$. Compared with control, PAL activity of Sixing $F_{1}$ was increased by $39.15 \%$ and $32.52 \%$ in leaves (Fig. $2 A$ ), as well as $27.19 \%$ and $22.31 \%$ in petioles (Fig. 2B), and $13.83 \%$ and $13.75 \%$ in stems (Fig. 2C) at the $7^{\text {th }}$ and $9^{\text {th }}$ days, 
respectively. In contrast, the PAL activity of $\operatorname{Jin}_{12} \mathrm{~F}_{1}$ was increased by $9.27 \%$ and $12.84 \%$ in leaves (Fig. $3 \mathrm{~A}$ ), as well as $11.86 \%$ and $11.75 \%$ in petioles (Fig. 3B), $7.12 \%$ and $6.16 \%$ in stems (Fig. $3 \mathrm{C}$ ) at the $7^{\text {th }}$ and

$9^{\text {th }}$ days, respectively. In addition, the expression level of $P A L$ activity was higher in leaves, lower in petioles and stems. Overall, the control treatment followed a similar trend as the other treatments in terms of the change of PAL activity during the course of the experimental period, but the control treatment had significantly lower PAL activity at a given measurement date starting at the $1^{\text {st }}$ day after inoculation.

\section{Levels of defense gene expression}

Higher transcript level of PAL gene expression was observed on different cultivars and tissues of pumpkin (Sixing $\mathrm{F}_{1}$ and $\operatorname{Jin}_{12} \mathrm{~F}_{1}$ ) after inoculated with the pathogen of $P$. xanthii (Fig. 4 and Fig. 5). Compared with pumpkin leaves that were inoculated with sterile water but not $P$. xanthii, the level of $P A L$ gene expression in different tissue (leaves, petioles and stems) of two cultivars Sixing $F_{1}$ (Fig. 4) and $\operatorname{Jin}_{12}$ F $_{1}$ (Fig. 5) were up-regulated and increased significantly after inoculation with $P$. xanthii at different time points. Also, there were significant differences at the level of $P A L$ gene expression between the cultivars of Sixing $\mathrm{F}_{1}$ and $\operatorname{Jin}_{12} F_{1}$ at different time points after inoculation. The level of $P A L$ gene expression in different tissues of Sixing $F_{1}$ was significantly higher than the cultivar of $\operatorname{Jin}_{12} F_{1}$. Similarly, among the three different tissues of the plant, the expression level of $P A L$ gene in different tissues was higher in leaves (Fig. 4A and Fig. 5A), lower in petioles (Fig. 4B and Fig. 5B) and stems (Fig. 4C and Fig. 5C). The level of $P A L$ gene expression reached its maximum at the $7^{\text {th }}$ and $9^{\text {th }}$ days after inoculation and thereafter it declined gradually in all the treatments. Our results indicate that the level of PAL gene expression in different tissues of cultivars showed a trend of increased first, and then decreased with the increase of inoculation time.

\section{Enhancement expression of PAL gene after inoculation with Podosphaera xanthii}

The enhancement changes of PAL gene expression were significantly different in different cultivars and tissues of pumpkin (Sixing $\mathrm{F}_{1}$ and $\operatorname{Jin}_{12} \mathrm{~F}_{1}$ ) after inoculated with $P$. xanthii (Fig. 6). However, the increased $P A L$ gene expression in Sixing $\mathrm{F}_{1}$ was significantly higher than the cultivar of $\operatorname{Jin}_{12} \mathrm{~F}_{1}$, as well as higher in leaves (Fig. 6A) than the petioles (Fig. 6B) and stems (Fig. 6C). The enhancement changes of $P A L$ gene expression in different tissues and cultivars of pumpkin also showed a trend of increased first, and thereafter it declined with the increase of inoculation time. The enhancement expressionof $P A L$ gene reached its maximum at the $9^{\text {th }}, 7^{\text {h }}$ and $7^{\text {th }}$ days in leaves (Fig. 6A), petioles (Fig. 6B) and stems (Fig. 6C) after inoculation and thereafter it declined.

\section{Lignin and total phenolics contents in pumpkin seedlings}


The cultivars of Sixing $F_{1}$ and $\operatorname{Jin}_{12} F_{1}$ with $P$. xanthii treatment increased the lignin and total phenolics contents in seedling leaves from 1 to 9 or 11 days, and peaked at the $9^{\text {th }}$ and $11^{\text {th }}$ days. The level of lignin and total phenolics contents of Sixing $F_{1}$ significantly higher in comparison to the cultivar of $\operatorname{Jin}_{12} F_{1}$. The average contents of lignin and total phenolics were significantly increased by $21.24 \%$ and $21.09 \%$ in Sixing $F_{1}$ seedlings leaves from 9 to 11 days after inoculation in comparison to the control under sterile water treatment, respectively. However, in the cultivars of $\operatorname{Jin}_{12} F_{1}$, the contents of lignin and total phenolics in the seedling leaves were increased by $12.38 \%$ and $18.65 \%$ from 9 to 11 days after inoculation, compared with the control under sterile water treatment, respectively (Table 4).

Table 4

Lignin and total phenolic content in different cultivars of Cucurbita pepo seedlings after inoculation with Podosphaera xanthii

\begin{tabular}{|c|c|c|c|c|c|c|c|c|}
\hline \multirow[t]{2}{*}{ Cultivars } & \multirow[t]{2}{*}{ Treatments } & \multicolumn{7}{|c|}{ Days post inoculation (dpi) } \\
\hline & & 1 & 3 & 5 & 7 & 9 & 11 & 13 \\
\hline & \multicolumn{8}{|c|}{ _-_-_ignin content (\% of cell wall dry weight)-_-_-_ } \\
\hline \multirow[t]{2}{*}{ Sixing $\mathrm{F}_{1}$} & Treatment & $2.56 \mathrm{a}$ & $2.89 \mathrm{a}$ & $3.28 \mathrm{a}$ & $5.08 \mathrm{a}$ & $6.56 \mathrm{a}$ & $6.52 \mathrm{a}$ & $6.13 \mathrm{a}$ \\
\hline & Control & $2.43 \mathrm{~b}$ & $2.78 \mathrm{~b}$ & $3.09 \mathrm{~b}$ & $4.25 b$ & $5.34 \mathrm{~b}$ & $5.45 b$ & $5.25 b$ \\
\hline \multirow[t]{2}{*}{$\operatorname{Jin}_{12} F_{1}$} & Treatment & $2.12 \mathrm{c}$ & $2.24 \mathrm{c}$ & $2.67 c$ & $3.11 \mathrm{c}$ & $3.98 \mathrm{c}$ & $4.02 \mathrm{c}$ & $3.96 \mathrm{c}$ \\
\hline & Control & $2.01 \mathrm{c}$ & $2.15 \mathrm{c}$ & $2.48 \mathrm{~d}$ & $2.81 \mathrm{~d}$ & $3.51 \mathrm{~d}$ & $3.61 \mathrm{~d}$ & $3.74 \mathrm{~d}$ \\
\hline & \multicolumn{8}{|c|}{ _- Total phenolics content (g FW)-____-_- } \\
\hline \multirow[t]{2}{*}{ Sixing $F_{1}$} & Treatment & $3.62 \mathrm{a}$ & $3.85 a$ & $3.98 \mathrm{a}$ & $4.29 \mathrm{a}$ & $4.79 \mathrm{a}$ & $4.81 \mathrm{a}$ & $4.25 \mathrm{a}$ \\
\hline & Control & $3.35 b$ & $3.42 b$ & $3.62 b$ & $3.98 b$ & $4.02 \mathrm{~b}$ & $3.91 \mathrm{c}$ & $4.06 \mathrm{~b}$ \\
\hline \multirow[t]{2}{*}{$\operatorname{Jin}_{12} F_{1}$} & Treatment & $3.34 \mathrm{~b}$ & $3.57 \mathrm{~b}$ & $3.72 \mathrm{~b}$ & $3.89 \mathrm{~b}$ & $4.21 \mathrm{~b}$ & $4.33 \mathrm{~b}$ & $3.98 \mathrm{bc}$ \\
\hline & Control & $3.01 \mathrm{c}$ & $3.12 \mathrm{c}$ & $3.23 c$ & $3.45 c$ & $3.64 \mathrm{c}$ & $3.56 \mathrm{~d}$ & $3.54 \mathrm{c}$ \\
\hline
\end{tabular}


Table 1

Specific PCR primers for PAL gene and Actin gene

\begin{tabular}{|ll}
\hline Number of primers & Primers sequence \\
\hline PAL (F) & 5'-AACTTCTCCTCAATGGCTTGGT-3' \\
\hline$P A L(\mathrm{R})$ & 5'-TGAAACATCAATCAAAGGGTTG-3' \\
\hline$A C T(\mathrm{~F})$ & 5'-TgYgACAATggAACWggAATg-3' $^{\prime}$ \\
\hline$A C T(\mathrm{R})$ & 5'-CATCTgYTggAARgTgCTgAg-3' \\
\hline Note: F represents forward, R represents reverse \\
\hline
\end{tabular}

\section{Discussion}

Previous studies have been demonstrated that the disease resistance screening in introduced germplasm was important to get resistant and tolerant germplasm for breeding new cultivars to control powdery mildew in field and greenhouse-grown pumpkins [27], but the mechanisms of pumpkin germplasm in resistance to Podosphaera xanthii infection remain unresolved because specific information about the improvement of antioxidative defense system and gene expression in different cultivars are virtually unknown at the physiological, biochemical and molecular levels. In the present study, we evaluated the ability and unveiled the mechanisms of two commercial pumpkincultivars in resistance to $P$. xanthii infection. Interestingly, we discovered that the cultivar of Sixing $F_{1}$ exhibited higher ability in resistance to $P$. xanthii infection, and less ROS accumulation, lower rates of lipid peroxidation, and higher level of PAL activity and gene expression, lignin and total phenolics contents than $\operatorname{Jin}_{12} F_{1}$. Thus, our results indicate that Sixing $F_{1}$ and $\operatorname{Jin}_{12} F_{1}$ can be considered as the resistant cultivar and susceptible cultivar, respectively, and the mechanism for their resistance to $P$. xanthii infection through enhancing the level of PAL activity and gene expression to reduce the ROS accumulation, and increase the lignin and total phenolics contents in their tissues to activate the defense system to prevent the pathogens infection. Our results will provide a vital theoretical basis and new insight for the mechanisms of different cultivars of pumpkinin resistance to $P$. xanthii infection. To the best of our knowledge, this is the first report suggesting that the cultivars of pumpkin in resistance to $P$. xanthii infection through stimulating the defense system response in different tissues.

De Oliveira Rabelo et al. (2017) reported that breeding for resistance is one of the best strategies to decrease powdery mildew damage, and for the selection of cucurbits cultivars in resistance to powdery mildew [28]. Our results showed that the cultivar of Sixing $\mathrm{F}_{1}$ exhibited higher ability in resistance to $P$. xanthii infection, whereas the cultivar of $\operatorname{Jin}_{12} \mathrm{~F}_{1}$ exhibited lower ability. The disease incidence and index of $\operatorname{Jin}_{12} F_{1}$ were significantly higher than Sixing $F_{1}$ at different time points after inoculation. Yan et al. [29] showed that the disease incidence of the cultivar of Guangban was significantly higher than the cultivars of Sanxing, Erxing, and Hongfu after inoculation with the pathogen of $P$. xanthii. However, our results indicate that the cultivar of Sixing $F_{1}$ presented higher ability in resistance to $P$. xanthii infection than 
$\operatorname{Jin}_{12} \mathrm{~F}_{1}$. Thus, the cultivar of Sixing $\mathrm{F}_{1}$ can be considered as the resistant cultivar in resistance to $P$. xanthii infection, whereas the cultivar of $\operatorname{Jin}_{12} F_{1}$ can be considered as the susceptible cultivar.

Furthermore, some previous studies have been reported that plants can produce the constitutive and induced mechanisms to defend themselves against pathogens attack [30,31], such as i.e. the rapid generation of hydrogen peroxide $\left(\mathrm{H}_{2} \mathrm{O}_{2}\right)$ and lipid peroxidation (MDA) have been considered as the important types of ROS and key biochemical indicators of oxidative damage in plants against pathogens infection [32-35]. In the present study, a significant increase in $\mathrm{H}_{2} \mathrm{O}_{2}$ and MDA generation in both pumpkin cultivars in response to $P$. xanthii infection, and the greatest accumulation of $\mathrm{H}_{2} \mathrm{O}_{2}$ and MDA were found in the susceptible cultivar $\operatorname{Jin}_{12} F_{1}$. In addition, it was interesting that a positive relationship was discovered between the high contents of $\mathrm{H}_{2} \mathrm{O}_{2}$ and MDA, and disease incidence and index. Similarly, Patykowski and Urbanek (2003) reported that the ability of tomato in resistance to Botrytis cinerea infection resulted from the early induction of $\mathrm{H}_{2} \mathrm{O}_{2}$ [14]. Meanwhile, the excess $\mathrm{ROS}$ can lead to the peroxidation of unsaturated lipids of membranes in plants [36], such as the accumulation levels of ROS led to the increased contents of MDA in both the resistant and susceptible cultivars of faba bean during the interaction of $B$. fabae [37]. Our results indicate that the induction of $\mathrm{H}_{2} \mathrm{O}_{2}$ and MDA in inoculated plants may be one of the pumpkin defense mechanisms against the invading pathogen infection, and the lower levels of ROS and MDA correlated with the susceptibility of pumpkin leaf tissues to infection with $P$. xanthii. El-Komy (2014) demonstrated that the resistant cultivar showed less ROS accumulation, a lower rate of lipid peroxidation and higher activity of the enzymatic ROS scavenging system compared with susceptible cultivar during the interaction of $B$. fabae [37].

In addition, plants can possess an inherent capacity to eliminate the harmful effects of reactive oxygen species (ROS) through the involvement of an antioxidative system that protects cell constituents from the oxidative damage [38]. Pathogenesis-related protein is one of the most important accumulated biotic components in plants to defend the pathogens after their attack and infection, including PAL, chitinase peroxidase, and other proteins [39]. Among all the pathogenesis-related proteins, PAL is the first enzyme in the phenylpropanoids pathway, which produces the precursors for lignin and phenolic secondary metabolites that may be enhanced after pathogen infection [40]. Also, PAL is one of the key genes in the phenylpropane synthesis pathway, and is closely related to plant resistance to external stresses [41]; PAL gene is among those most relevantly upregulated in plants that develop resistance to phytopathogens [24]. Our results found that PAL plays a significant role in inducing plant systemic resistance, including the PAL activity and gene expression in different tissues of pumpkin at different time points were activated by $P$. xanthii inoculation. Similar studies revealed that PAL plays a significant role in plant resistance to pathogens infection, which involved in induced systemic resistance [42]; Chen et al. (2014) reported that the expression level of PAL activity andgene in cucumber leaves were activated by $P$. xanthii inoculation [41]. Additionally, we found that the activity of PAL and the expression level of PAL gene in different tissues of resistant cultivar were significantly higher than the susceptible cultivar, as well as higher expression in leaves than petioles and stems. Similarly, higher transcript levels of PAL activity and gene expression were found in pathogens inoculated plants than the no-inoculated plants. Several 
previous studies also reported that the increased levels of the gene expression or the enzymic activity have been observed in plants after inoculation with pathogenic microbe [43-45]. Thus, our results indicate that PAL gene plays a significant role in coding the PAL activity to induce the ability of pumpkin resist to $P$. xanthii infection. The expression level of PAL gene in different tissues of pumpkin cultivars reached its maximum at the $7^{\text {th }}$ and $9^{\text {th }}$ days after inoculation and thereafter it declined with the increase of inoculation time. Gao et al. [46] revealed that the relative expression level of CSPAL gene in cucumbers exhibited a trend of increased first after inoculation with powdery mildew, and thereafter decreased with the increase of inoculation time.

PAL is a key and rate-limiting enzyme in catalyzing phenylalanine to trans-cinnamic acid to improve the disease resistance of plants by promoting the synthesis of phenolic substances and lignin [47]. Additionally, phenylalanine lignification is one of the physical and biochemical changes of plant cell wall which could be induced by pathogen infection [48], and also phenolic compound plays an important role in participating in the defense mechanism against fungal infection $[49,50]$. Our results found that a significant increase in lignin and total phenolics contents in seedling leaves of Sixing $F_{1}$ and $\operatorname{Jin}_{12} F_{1}$ after treatment with $P$. xanthii, the level of lignin and total phenolics contents in the cultivar of Sixing $\mathrm{F}_{1}$ significantly higher in comparison to the cultivar of $\operatorname{Jin}_{12} F_{1}$. Similarly, Muslim et al. (2019) revealed that the lignin deposition is an important step to prevent systemically immunised cucumber plants from pathogen of Colletotrichum orbiculare infection [51], and also the level of total phenolics was increased in cucumber seedlings after inoculated with the $P$. xanthii [41].

\section{Conclusions}

In summary, the results of our study suggest that Sixing $F_{1}$ can be considered as the resistant cultivar, and $\operatorname{Jin}_{12} F_{1}$ can be considered as the susceptible cultivar. One novel possible mechanism is related to the pumpkin cultivars in resistance to $P$. xanthii infection through enhancing the level of $P A L$ activity and gene expression to promote the synthesis of phenolic substances and lignin, and reduce the ROS accumulation to activate the defense system in different tissues to prevent the pathogens infection finally. However, more research is needed to determine other defense genes in pumpkins that coding the pathogenesis-related protein expression in resistance to $P$. xanthii infection in the future.

\section{Materials And Methods}

Experiments were carried out at the Laboratory of Plant Pathology, College of Plant Protection; Gansu Provincial Key Laboratory of Arid Land Crop Science, Gansu Agricultural University. All treatments in the experiments described below had twelve replicates.

\section{Seeds treatment}


Seeds of two commercial pumpkin cultivars (Sixing $F_{1}$ and $\operatorname{Jin}_{12} F_{1}$ ) were selected and kindly provided by the company of Wuwei Golden Apple co. LTD. Seeds with a uniform size were surface-sterilized with $5 \%$ $\mathrm{NaOCl}(\mathrm{v} / \mathrm{v})$ for $3 \mathrm{~min}$. After disinfection, all the seeds were rinsed with sterile water for 5 times, and then were soaked in sterile water for 12 hours for germination.

\section{Greenhouse experiments}

The experiments were carried out in the greenhouse of Gansu Agricultural University in August, 2013. Seeds of two pumpkin commercial cultivars were germinated in 9-cm diameters Petri dishes, and covered with two layers of absorbent cotton and blotter papers in a constant temperature at $25^{\circ} \mathrm{C}$ for germination. Thereafter, the germinated seeds with a uniform size were planted in 12-cm diameters pots that contained $500 \mathrm{~g}$ of sterilized soil. Each pot was planted with 8 seeds and each cultivar with 12 pots (a total of 96 plants) after germination. The experiment was arranged in a completely randomized design with twelve replications, took place in a greenhouse with the inside temperature maintained between $25^{\circ} \mathrm{C}$ and $20^{\circ} \mathrm{C}$ (day and night), the supplemental photoperiod was 16/8 hours light/dark, and the relative humidity at $60 \%$. Irrigation was done twice weekly at each treatment and control.

\section{Podosphaera xanthii identification and inoculum preparation}

Pumpkin leaves infected with the pathogen of powdery mildew were collected from the field (Wuwei, China) in July 15, 2013 for microscopic observation of the pathogen. The conidia observed under light microscope (E200, Germany) were oidium type and conidiospore with cylindrical fibrosin bodies of conidia which was identified to be Podosphaera xanthii according to the earlier published papers $[52,53]$. Thereafter, artificial inoculation of host plants seedlings were performed by manually through dusting the sporulated leaves and $P$. xanthii isolate in host plants were kept for 20 days in greenhouse. The tested plants were inoculated at the 4-true leaf stage with the suspension of powdery mildew fungal pathogen $P$. xanthii spores by smear method, and 5 plants with relatively consistent growth were selected for each pot, and each plant was inoculated with 3 leaves. After that, the inoculated seedlings were placed in a greenhouse at $25^{\circ} \mathrm{C}$ and $20^{\circ} \mathrm{C}$ (day and night), relative humidity of $60 \%$ and light of $16 / 8$ hours for development of powdery mildew. Control plants (mock-inoculated) were inoculated with the same volume of sterile water and maintained separately from the inoculated plants in the same greenhouse. The seedlings disease incidence, disease index $\mathrm{H}_{2} \mathrm{O}_{2}, \mathrm{MDA}$, lignin and total phenolics contents, and the level of PAL activity and gene expression at different time points in each treatment and control were recorded and calculated every 2 days after inoculation.

\section{Disease incidence and index determination}


Seedlings disease incidence and index were observed and recorded every 2 days post inoculation (dpi) for both the inoculated and mock-inoculated plants, and collections continued for 1, 3, 5, 7, 9, 11 and 13 dpi from both cultivars of Sixing $F_{1}$ and $\operatorname{Jin}_{12} F_{1}$. Five plants from each treatment and control were used as one independent replicate per time point. Disease severity was recorded on individual pot of each cultivar. Based on the powdery mildew symptoms developed on the host plants, a 1 to 9 scales of increasing disease severity were used according to the standard described by Liu et al.(2006) [54].

Scale levels:

0: no symptoms;

1: the infected areas less than $30 \%$ in the front of leaves, and no symptoms in the reverse of leaves;

3: the infected areas greater than $30 \%$ in the front of leaves, and less than $10 \%$ in the reverse of leaves;

5: the infected areas greater than $30 \%$ and $10 \%$ in the front and reverse of leaves, respectively, and a few lesions appeared on the petioles;

7: the powdery mildew covered in the front of leaves and the infected areas greater than $10 \%$ in the reverse of leaves, and more lesions appeared on the petioles and a few on the main stems;

9: the powdery mildew covered in the front of leaves, petioles and main stems, and the infected areas greater than $10 \%$ in the reverse of leaves.

The calculation formulas of disease incidence and index as follows:

Disease incidence $(\%)=(\mathrm{NIL} / \mathrm{TNIL}) \times 100$.

where NIL is number of infected leaves, and TNIL is total number of investigated leaves.

Disease index $=(\Sigma N D L G L) /(T N I L ~ H G L) 100$.

where NDL is the number of diseased leaves in each lever; GL is grade levels; TNIL is total number of investigated leaves; $\mathrm{HGL}$ is the highest grade level.

\section{Hydrogen peroxide $\left(\mathrm{H}_{2} \mathrm{O}_{2}\right)$ and lipid peroxidation (MDA) contents determination}

For the determination of $\mathrm{H}_{2} \mathrm{O}_{2}$ contents in different cultivars of pumpkin seedling leaves, $0.5 \mathrm{~g}$ fresh leaf samples were homogenized in $5 \mathrm{ml}$ of precooled $\mathrm{HClO}_{4}(1.0 \mathrm{M})$ using the pre-chilled mortar and pestle. Thereafter, the reaction mixture was centrifuged at $10,000 \mathrm{~g}$ for $10 \mathrm{~min}$, and the contents of $\mathrm{H}_{2} \mathrm{O}_{2}$ in extracts were determined and calculated according to the method described by Willekens et al. (1997) [55]. The contents of $\mathrm{H}_{2} \mathrm{O}_{2}$ were expressed as $\mu \mathrm{mol} \mathrm{g}{ }^{-1} \mathrm{FW}$. 
The level of lipid peroxidation was determined by quantifying the MDA contents in different cultivars of pumpkin seedlings according to the method described by Hodges et al. (1999) [56] and Tian et al. (2015) [57] with some modifications. For the determination of the accumulation of MDA in pumpkin seedling leaves, $0.5 \mathrm{~g}$ fresh leaf samples were homogenized in $2.5 \mathrm{ml}$ of $0.1 \%$ trichloroacetic acid and the homogenate. Afterwards, the reaction mixture was centrifuged at $10,000 \mathrm{~g}$ for $15 \mathrm{~min}$ and the absorbance of supernatant was recorded at $532 \mathrm{~nm}$ wavelength. The content of MDA was expressed as nmol g ${ }^{-1} \mathrm{FW}$.

\section{PAL activity determination}

Fresh pumpkin seedling leaf, petiole and stem samples of $0.5 \mathrm{~g}$ were homogenized in $6 \mathrm{ml}$ ice-cold borate buffer $(5 \mathrm{mM}, \mathrm{pH} 8.8)$ using pre-chilled mortar and pestle, respectively. The supernatant of homogenates were collected and used as crude extracts after centrifuging at $8,000 \mathrm{~g}$ for $20 \mathrm{~min}$ at $4^{\circ} \mathrm{C}$. Thereafter, the supernatant was mixed with $0.02 \mathrm{M}$ phenylalanine and distilled water to obtain the extractions. The reaction mixtures were placed in a thermostatic water bath at $30^{\circ} \mathrm{C}$ for $30 \mathrm{~min}$ and then measured at 290 $\mathrm{nm}$. For the determination of PAL activity, the crude extraction was measured according to the method described by Hu et al. (2009) [61] and Ruiz et al. (1999) [62]. The activity of PAL was expressed as U min ${ }^{-}$ ${ }^{1} \mathrm{~g}^{-1} \mathrm{FW}$.

\section{Total RNA extraction and first strand cDNA synthesis}

The samples of leaves, petioles and stems were collected every 2 days post inoculation (dpi) for both the inoculated and mock-inoculated seedlings, and the collections continued for 1, 3, 5, 7, 9, 11 and $13 \mathrm{dpi}$ from both cultivars of Sixing $F_{1}$ and $\operatorname{Jin}_{12} F_{1}$ fortotal RNA extraction. Five plants from each treatment were used as one independent replicate per time point. Total RNA was extracted from control and treated frozen leaves, petioles and stems samples performed immediately using the Tiangen RNA Simple Total RNA Kit (Tiangen Biotechnology, Beijing, China) according to the manufacturer's instructions. Thereafter, total RNA was stored at $-80^{\circ} \mathrm{C}$ until use. The quantity and quality of total RNA were measured and determined using a Nanodrop ND-2000 spectrophotometer (Nanodrop Technologies, Waltham, MA, USA), and only high-quality RNA samples were used for subsequent experiments. First strand synthesis of total RNA was carried out employing an oligo (dT) primer mix and a random primer mix. Two microliters of total RNA was reversely transcribed using the M-MuLV First Stand DNA Synthesis Kit (Sangon Biotech, Shanghai, China) for the first-strand cDNA synthesis with oligo-dT18 primer priming method according to the manufacturer's instructions.

\section{Quantitative real-time PCR (qRT-PCR) analysis}

The level of $P A L$ gene expression was determined in pumpkin leaves, petioles and stems at different time points after inoculation with $P$. xanthii or sterile water in each treatment and control. qRT-PCR was 
performed using a SYBR Premix Ex Taq kit (Takara Biotechnology, Dalian, China) following the manufacturer's instructions. The sequences of the forward and reverse primer pairs used for qRT-PCR analysis were designed according to the EST sequences of pumpkin in NCBI using Primer Express 5.0 software that amplifies the target genes. The actin gene of pumpkin was used as an internal control. The level of $P A L$ gene expression was determined using the method of $2^{-\Delta \Delta C t}$ [63]. The gene specific primers used for this analysis are shown in Table 5.

\section{Leaf cell wall isolation and lignin content determination}

The leaf cell wall of different cultivars of pumpkin seedlings were isolated according the method described by Eskandari et al. (2018) [58]. A $0.5 \mathrm{~g}$ of fresh leaf samples were frozen and ground to powder using the liquid nitrogen. The powder samples were homogenized in distilled water and then centrifuged at $10,000 \mathrm{~g}$ for $10 \mathrm{~min}$. The precipitation was washed with absolute ethanol, and rinsed in chloroform and methanol $(v / v=1: 2)$ and then washed with acetone for three times. The cell wall pellet was filtered and finally dried overnight at $35^{\circ} \mathrm{C}$. The residue (cell wall) was collected and kept in a desiccator at room temperature until use.

The content of lignin was determined and assayed by following the procedure of liyama and Wallis (1990) [59] with a minor modification. A $5 \mathrm{mg}$ of cell wall preparation was treated with a mixture $(2.5 \mathrm{ml})$ that consisted of $5 \%(\mathrm{w} / \mathrm{w})$ acetyl bromide and $\mathrm{AcHO}$, and $0.1 \mathrm{ml}$ of $70 \% \mathrm{HClO}$ at $70^{\circ} \mathrm{C}$ for $30 \mathrm{~min}$. Finally, the reaction mixture was treated with $50 \mathrm{ml}$ that contained $2 \mathrm{M} \mathrm{NaOH}$ and $\mathrm{AcHO}$ after cooling. The lignin content was determined by measuring the absorbance at $280 \mathrm{~nm}$ using a specific absorption coefficient of $20.0 \mathrm{~g}^{-1} \mathrm{I} \mathrm{cm}^{-1}$.

\section{Total phenolics content determination}

The contents of total phenolics were measured according to the method described by Singleton and Rossi (1965) with a minor modification [60]. A $0.5 \mathrm{~g}$ fresh leaf samples were ground with a small amount of quartz sand, and thereafter extracted in $70 \%$ ethanol $(10 \mathrm{ml})$ for $10 \mathrm{~min}$. The reaction mixture was centrifuged at $12,000 \mathrm{~g}$ for $20 \mathrm{~min}$. The supernatant of the reaction mixture was collected and used to measure the total phenolic content, and expressed as $\mathrm{mg} \mathrm{g}^{-1} \mathrm{FW}$.

\section{Statistical analysis}

The data were subjected to variance analysis (ANOVA) using SPSS Version 16.0 (SPSS Inc., Chicago, IL). Each experiment had twelve replications. Duncan's multiple range test was computed using standard error and $T$ values of adjusted degrees of freedom. The significant differences between the treatments were considered at the level of $p<0.05$. The data of disease incidence, index and gene expression levels 
of two commercial pumpkin cultivars (Sixing $F_{1}$ and $\operatorname{Jin}_{12} F_{1}$ ) were calculated according the formulas as described previously.

\section{Declarations}

\section{Acknowledgments}

The authors would like to thank Dr. Yingyu Xue (Professor of Plant Pathology, Gansu Agricultural University, China) for his helpful discussion and critical review of the manuscript.

\section{Author contributions}

SZ conceived the experiments with the help of BX. SZ collected and prepared the fungus and pumpkin seedling samples, and performed the mechanisms of different cultivars of pumpkin in resistance to Podosphaera xanthii infection and extracted the total RNA from pumpkin seedling samples. JL and SZ performed qRT-PCR, analyzed the data, and interpreted the results. SZ wrote the manuscript. SZ and BX revised and approved the final manuscript.

\section{Funding}

This work was supported by Scientific Research Start-up Funds for Openly-recruited Doctors (project 2017RCZX-07); National Natural Science Foundation of China (project 31460526); Special Funds for Discipline Construction (project GAU-XKJS-2018-147).

\section{Availability of data and materials}

Not applicable.

\section{Competing interests}

The authors declare that they have no competing interests.

\section{Consent for publication}

Not applicable.

\section{Ethics approval and consent to participate}


Not applicable.

\section{References}

1. Hafez YM, El-Nagar AS, Elzaawely AA, Kamel S, Maswada HF. Biological control of Podosphaera xanthii the causal agent of squash powdery mildew disease by upregulation of defense-related enzymes. Egyptian J. Biol. Pest Cont. 2018, 28: 57.

2. Barickman TC, Horgan TE, Wilson JC. Efficacy of fungicide applications and powdery mildew resistance in three pumpkin cultivars. Crop Prot. 2017, 101: 90-4.

3. Shi ZQ, Wang F, Zhou W, Zhang P, Fan YJ. Application of osthol induces a resistance response against powdery mildew in pumpkin leaves. Int. J. Mol. Sci. 2007, 8: 1001-12.

4. Cohen Y, Baider A, Petrov L, Sheck L, Voloisky V. Cross-infectivity of Sphaerotheca fuliginea to watermelon, melon and cucumber. Acta Hortic. 2000, 510: 85-8.

5. El-Naggar M, El-Deeb H, Ragab S. Applied approach for controlling powdery mildew disease of cucumber under plastic houses. Pak. J. Agric: Agric. Eng. Vet. Sci. (Pakistan) 2012, 28(1): 54-64.

6. Tanaka K, Fukuda M, Amaki Y. Importance of prumycin produced by Bacillus amyloliquefaciens SD32 in biocontrol against cucumber powdery mildew disease. Pest Manag. Sci. 2017, 73: 2419-28.

7. El-Alfy AT, Schlenk D. Effect of 17-beta-estradiol and testosterone on the expression of flavincontaining monooxygenase and the toxicity of aldicarb to Japanese medaka, Oryzias latipes. Toxicol. Sci. 2002, 68: 381-8.

8. Faostat: Agricultural structure (production, price, value) (http://apps.fao.org/faostat). Food and Agriculture Organization, Rome, 2010.

9. Abdel-Monaim M, Abdel-Gaid M, Armanious H. Effect of chemical inducers on root rot and wilt diseases, yield and quality of tomato. Int. J. Agric. Sci. 2012, 7: 211-20.

10. Dik AJ, Verhaar MA, Bélanger RR. Comparison of three biological control agents against cucumber powdery mildew (Sphaerotheca fuliginea) in semi-commercial scale glasshouse trials. Eur. J. Plant Pathol. 1998, 104: 413-23.

11. Smith PG. Powdery mildew resistance in cucumber. Phytopathology 1948, 38: 1027-8.

12. Morishita M, Sugiyama K, Saito T, Sakata Y. Powdery mildew resistance in cucumber. Japan Agr. Res. Q. 2003, 37(1): 7-14.

13. Dangl J, Jones JDG. Plant pathogens and integrated defense responses to pathogens. Nature 2001, 411: 826-34.

14. Patykowski J, Urbanek $\mathrm{H}$. Activity of enzymes related to $\mathrm{H} 2 \mathrm{O} 2$ generation and metabolism in leaf apoplastic fraction of tomato leaves infected with Botrytis cinerea. J. Phytopathol. 2003, 151: 15361.

15. Dong CJ, Cao N, Zhang ZG, Shang QM. Phenylalanine ammonia-lyase gene families in cucurbit species: structure, evolution, and expression. J. Integr. Agr. 2016, 15: 1239-55. 
16. Hou L, Wang LN, Wu XL, Gao W, Zhang JX, Huang CY. Expression patterns of two pal genes of Pleurotus ostreatus across developmental stages and under heat stress. BMC Microbiol. 2019, 19: 231.

17. Irisarri P, Zhebentyayeva T, Errea P, Pina A. Differential expression of phenylalanine ammonia lyase (PAL) genes implies distinct roles in development of graft incompatibility symptoms in Prunus. Sci. Hortic. 2016, 204: 16-24.

18. Kamalipourazad M, Sharifi M, Maivan HZ, Behmanesh M, Chashmi NA. Induction of aromatic amino acids and phenylpropanoid compounds in Scrophularia striata Boiss. cell culture in response to chitosan-induced oxidative stress. Plant Physiol. Biochem. 2016, 107: 374-84.

19. Han C, Li J, Jin P, Li X, Wang L, Zheng Y. The effect of temperature on phenolic content in wounded carrots. Food Chem. 2017, 215: 116-23.

20. Vogt T. Phenylpropanoid biosynthesis. Mol. Plant 2010, 3(1): 2-20.

21. Wang XH, Gong M, Tang L, Zheng S, Lou JD, Ou L, Gomeslaranjo J, Zhang C. Cloning, bioinformatics and the enzyme activity analyses of a phenylalanine ammonia-lyase gene involved in dragon's blood biosynthesis in Dracaena cambodiana. Mol. Biol. Rep. 2013, 40(1): 97-107.

22. Jiang Y, Xia N, Li X, Shen W, Liang L, Wang C, Wang R, Peng F, Xia B. Molecular cloning and characterization of a phenylalanine ammonia-lyase gene (LrPAL) from Lycoris radiata. Mol. Biol. Rep. 2011, 38(3): 1935-40.

23. Zhang C. Cloning, bioinformatics and the enzyme activity analyses of a phenylalanine ammonialyase gene involved in dragon's blood biosynthesis in Dracaena cambodiana. Mol. Biol. Rep. 2013, 40(1): 97-107.

24. Kim DS, Hwang BK. An important role of the pepper phenylalanine ammonia-lyase gene (PAL1) in salicylic acid-dependent signalling of the defence response to microbial pathogens. J. Exp. Bot. 2014, 65: 2295-306.

25. Lee HJ, Park KH, Shim JH, Park R, Kim Y, Cho J, Hwangbo H, Kim Y, Cha G, Krishnan H, Kim K. Quantitative changes of plant defense enzymes in biocontrol of pepper (Capsicium annuum L.) late blight by antagonistic Bacillus subtilis HJ927. J. Microbiol. Biotechnol. 2005, 15: 1073-9.

26. Li Y, Kim JI, Pysh L, Chapple C. Four isoforms of Arabidopsis thaliana 4-coumarate: CoA ligase (4CL) have overlapping yet distinct roles in phenylpropanoid metabolism. Plant Physiol. 2015, 169: 240921.

27. Luitel BP, Kim SG, Sung JS, Hur OS, Mun SY, Rhee JH, Baek HJ, Ryu KY, Ko HC. Screening of pumpkin (Cucurbita spp.) germplasm for resistance to powdery mildew at various stages of seedlings growth. Res. Plant Dis. 2016, 22(3): 133-44.

28. de Oliveira Rabelo H, da Silva Santos L, Diniz GMM, Marin MV, Braz LT, McCreight JD. Cucurbits powdery mildew race identity and reaction of melon genotypes. Pesqui. Agropecu. Trop. 2017, 47: 440-7.

29. Yan HX, Xu BL, Liang QL, Xue YY, Chen RX, Liang ZF. Effects of chlorophyll content and stoma density on pumpkin resistance to powdery mildew. Plant Prot. 2009, 35(1): 79-81. 
30. Rémus-Borel W, Menzies JG, Bélanger R. R. Silicon induces antifungal compounds in powdery mildew-infected wheat. Physiol. Mol. Plant Pathol. 2005, 66: 108-15.

31. Fofana B, Mcnally DJ, Labbé C, Boulaner R, Benhamou N, Séguin A, Bélanger RR. Milsana-induced resistance in powdery mildew-infected cucumber plant correlates with the induction of chalcone synthase and chalcone isomerase. Physiol. Mol. Plant Pathol. 2002, 61: 121-32.

32. Garcia-Limones C, Hervas A, Navas-Cortes JA, Jimenez-Diaz RM, Tena MM. Induction of an antioxidant enzyme system and other oxidative stress markers associated with compatible and incompatible interactions between chickpea (Cicer arietinum L.) and Fusarium oxysporum f. sp. ciceris. Physiol. Mol. Plant Pathol. 2002, 61: 325-37.

33. Mellersh DG, Foulds IV, Higgins VJ, Heath MC. H2O2 plays different roles in determining penetration failure in three diverse plant-fungal interactions. Plant J. 2002, 29: 257-68.

34. Mandal S, Das RK, Mishra S. Differential occurrence of oxidative burst and antioxidative mechanism in compatible and incompatible interactions of Solanum lycopersicum and Ralstonia solanacearum. Plant Physiol. Biochem. 2011, 49: 117-23.

35. Chavan V, Bhargava S, Kamble A. Temporal modulation of oxidant and antioxidative responses in Brassica carinata during $ß$-aminobutyric acid-induced resistance against Alternaria brassicae. Physiol. Mol. Plant Pathol. 2013, 83: 35-9.

36. Apel K, Hirt H. Reactive oxygen species: metabolism, oxidative stress, and signal transduction. Annu. Rev. Plant Biol. 2004, 55: 373-99.

37. El-Komy MH. Comparative analysis of defense responses in chocolate spot-resistant and susceptible faba bean (Vicia faba) cultivars following infection by the necrotrophic fungus Botrytis fabae. Plant Pathol. J. 2014, 30: 355-66.

38. Gill SS, Tuteja N. Reactive oxygen species and antioxidant machinery in abiotic stress tolerance in crop plants. Plant Physiol. Biochem. 2010, 48: 909-30.

39. Tuzun S, Rao MN, Vogeli U, Schardi CL, Kuc J. Induced systemic resistance to blue mold: early induction and accumulation of $ß-1$, 3-glucanases, chitinases, and other pathogenesis-related proteins (ß-proteins) in immunized tobacco. Phytopathology 1989, 79: 979-83.

40. Sticher L, Mauch-Mani B, Metraux JP. Systemic acquired resistance. Annu. Rev. Phytopathol. 1997, 35: $235-70$.

41. Chen J, Fernandez D, Wang DD, Chen YJ, Dai GH. Biological control mechanisms of D-pinitol against powdery mildew in cucumber. Physiol. Mol. Plant P. 2014, 88: 52-60.

42. Mauch-mani B, Slusarenko AJ. Production of salicylic acid precursors is a major function of phenylalanine ammonia-lyase in the resistance of Arabidopsis to Peronospora parasitica. Plant Cell 1996, 8: 203-12.

43. Vogeli-Lange R, Hansen-Gehri A, Boller T, Meins F. Induction of the defense-related glucanohydrolase, ß-1, 3-glucanase and chitinase, by tobacco mosaic virus infection of tobacco leaves. Plant Sci. 1988, 54: 171-6. 
44. Roby D, Broglie K, Cressman R, Biddle P, Chet I, Broglie R. Activation of a bean chitinase promoter in transgenic tobacco plants by phytopathogenic fungi. Plant Cell 1990, 2: 999-1007.

45. Conrads-Strauch J, Dow JM, Milligan DE, Parra R, Daniels MJ. Induction of hydrolytic enzymes in Brassica campestris in response to pathovars of Xanthomonas campestris. Plant Physiol. 1990, 93: 238-43.

46. Gao SH, Xu XW, Zhang RY, Qi XH, Xu Q, Chen XH. Cloning of CsPAL gene and its expression analysis in response to powdery mildew infection. Mol. Plant Breed. 2019, 17: 1757-62.

47. Babu AN, Jogaiah S, Ito S, Nagaraj AK. Improvement of growth, fruit weight and early blight disease protection of tomato plants by rhizosphere bacteria is correlated with their beneficial traits and induced biosynthesis of antioxidant peroxidase and polyphenol oxidase. Plant Sci. 2015, 231: 6273.

48. Daayf F, Schmitt A, Bélanger RR. Evidence of phytoalexins in cucumber leaves infected with powdery mildew following treatment with leaf extracts of Reynoutria sachalinensis. Plant Physiol. 1997, 113: 719-27.

49. Dai GH, Andary C, Mondolot-Cosson L, Boubals D. Involvement of phenolic compounds in the resistance of grapevine callus to downy mildew (Plasmopara viticola). Eur. J. Plant Pathol. 1995, 101: $541-7$.

50. Moharam MHA. Induction of defence-related biochemical changes in okra leaves to powdery mildew disease by several plant-derived agents. Arch Phyt. Plant Prot. 2013, 46: 1667-82.

51. Muslim A, Hyakumachi M, Kageyama K, Suwandi S. Induction of systemic resistance in cucumber by hypovirulent binucleate Rhizoctonia against anthracnose caused by Colletotrichum orbiculare. Trop. Life Sci. Res. 2019, 30: 109-22.

52. McGrath MT, Thomas CE. Powdery Mildew. In Compendium of Cucurbit Diseases, ed.; Zitter T, Hopins ADL, Thomas CE. APS Press: St. Paul, MN, USA, 1996; pp. 28-30.

53. Shin HD. Erysiphaceae of Korea. National Institute of Agricultural Science and Technology: Suwon, Korea, 2000; pp. 227-235.

54. Liu XB, Zhang JH, Cui CS. Identification of pathogen and evaluation the resistance to pumpkin powdery mildew in Heilongjiang Province. China Cucurb. Veget. 2006, 1: 10-13.

55. Willekens $H$, Chamnongpol S, Davey M, Schraudner M, Langebartels $C$, VanMontagu M, Inze $D$, VanCamp W. Catalase is a sink for $\mathrm{H} 2 \mathrm{O} 2$ and is indispensable for stress defence in $\mathrm{C}-3$ plants. EMBO J. 1997, 16: 4806-16.

56. Hodges DM, DeLong JM, Forney CF, Prange RK. Improving the thiobarbituric acid-reactive-substances assay for estimating lipid peroxidation in plant tissues containing anthocyanin and other interfering compounds. Planta 1999, 207: 604-11.

57. Tian XY, He MR, Wang ZL, Zhang JW, Song YL, He ZL, Dong YJ. Application of nitric oxide and calcium nitrate enhances tolerance of wheat seedlings to salt stress. Plant Growth Regul. 2015, 77: 343-56. 
58. Eskandari S, Khoshgoftarmanesh AH, Sharifnabi B. The effect of foliar-applied manganese in mineral and complex forms with amino acids on certain defense mechanisms of cucumber (Cucumis sativus L.) against powdery mildew. J. Plant Growth Regul. 2018, 37: 481-90.

59. liyama K, Wallis AFA. Determination of lignin in herbaceous plants by an improved Acetyl Bromide procedure. J. Sci. Food Agric. 1990, 51: 145-61.

60. Singleton VL, Rossi JA. Colorimetry of total phenolics with phosphomolybdic phosphotungstic acid reagents. Am. J. Enol. Vitic. 1965, 16: 144-58.

61. Hu ZH, Zhang W, Shen YB, Fu HJ, Su XH, Zhang ZY. Activities of lipoxygenase and phenylalanine ammonia lyase in poplar leaves induced by insect herbivory and volatiles. J. For. Res. 2009, 20: 3726.

62. Ruiz JM, Garcia PC, Rivero RM, Romero L. Response of phenolicmetabolism to the application of carbendazim plus boron in tobacco. Physiol. Plant 1999, 106: 151-7.

63. Livak KJ, Schmittgen TD. Analysis of relative gene expression data using real-time quantitative PCR and the 2- $\Delta \Delta$ Ct method. Methods 2001, 25: 402-8.Table 1 The disease incidence of different cultivars of Cucurbita pepo after inoculation with Podosphaera xanthii

\section{Figures}
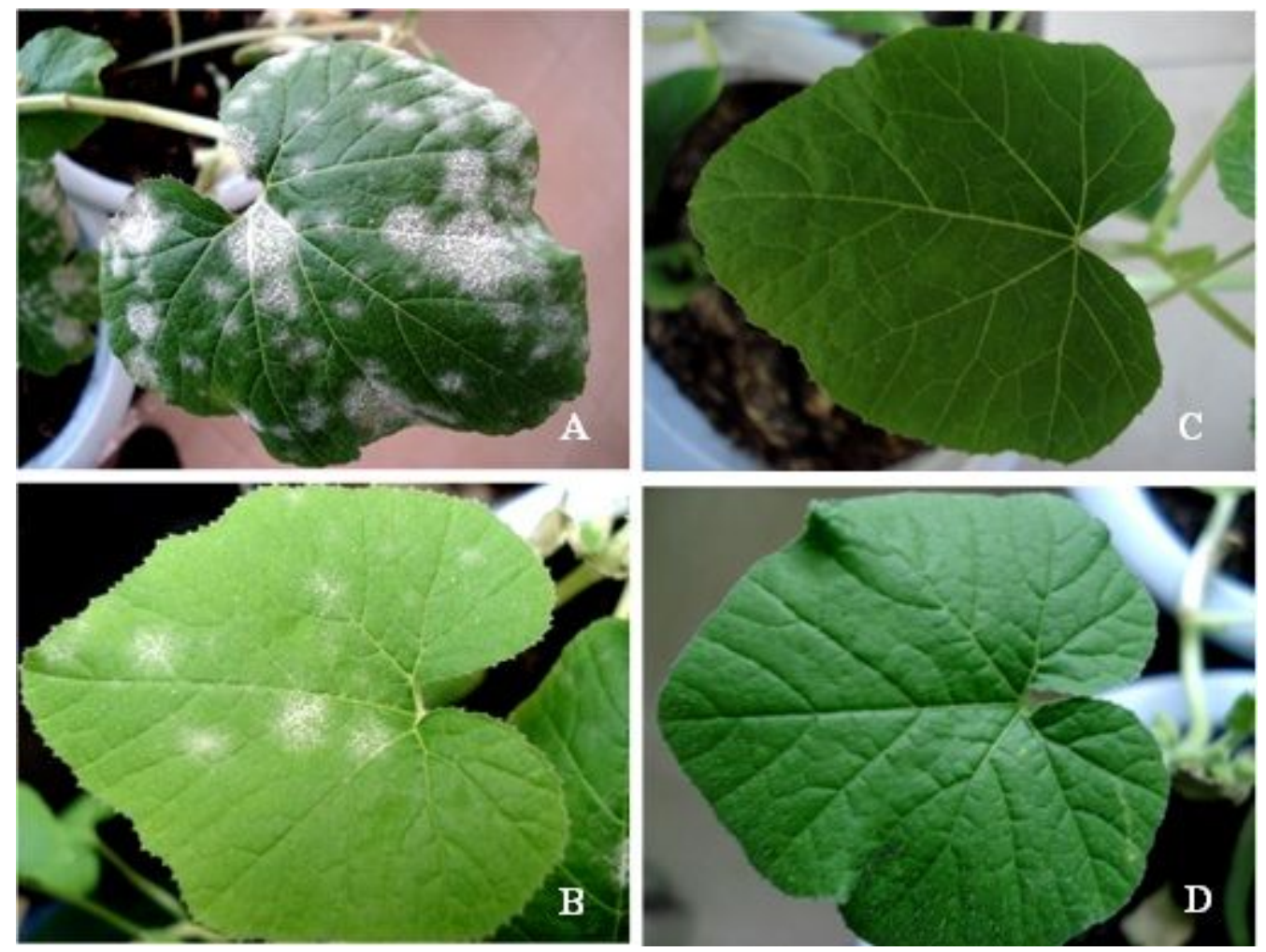

Figure 1

The symptoms of different cultivars of Cucurbita pepo after inoculation with the pathogen of Podosphaera xanthii at the 13th day. Where A the cultivar of Jin12 F1 after inoculation with P. xanthii; B 
the cultivar of Sixing F1 after inoculation with P. xanthii; C the cultivar of Jin12 F1 after inoculation with sterile water but not P. xanthii; D the cultivar of Sixing F1 after inoculation with sterile water but not P. xanthii
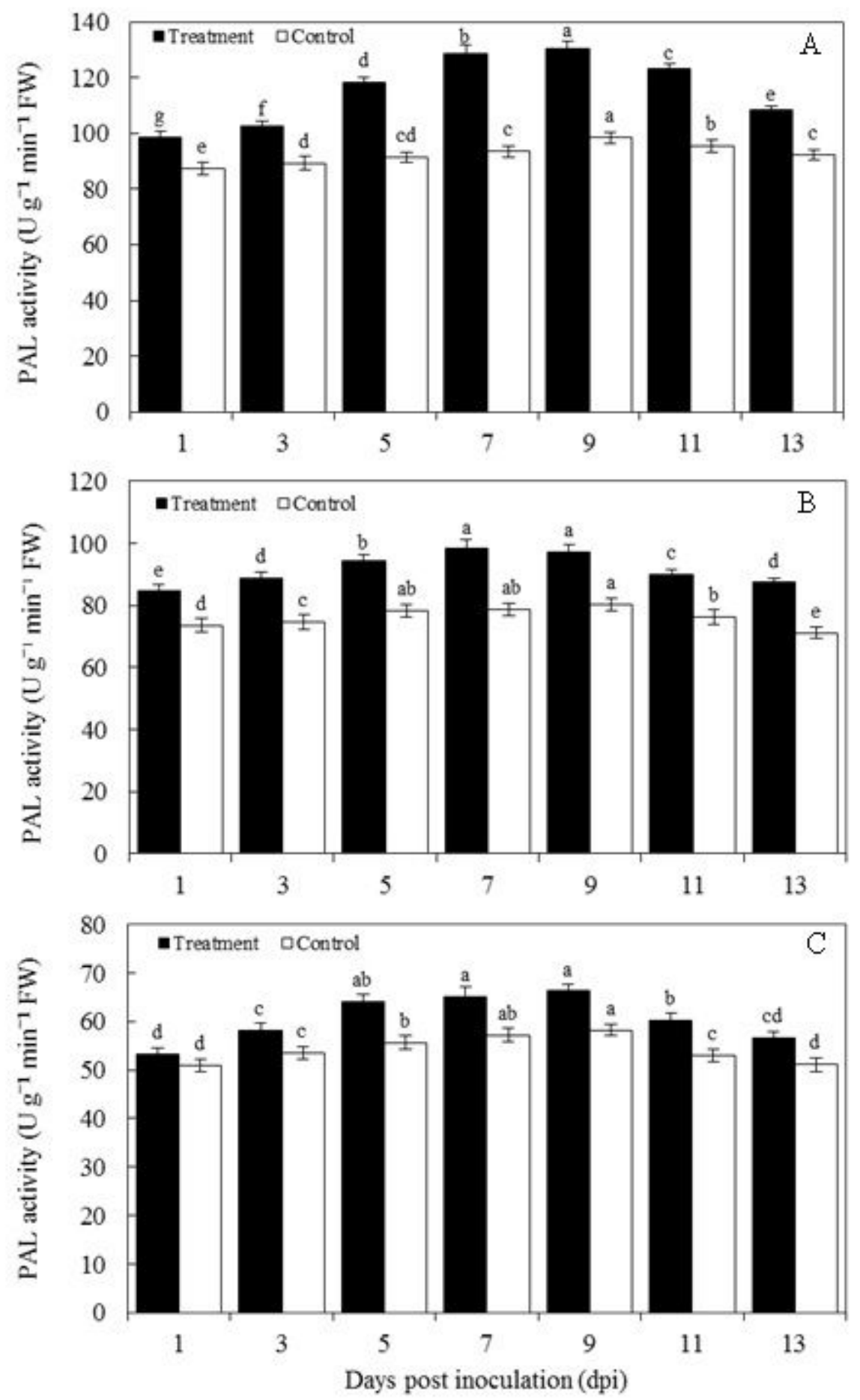

Figure 2

PAL activity in the (A) leaves, (B) petioles, and (C) stems of Sixing F1 at different time points after inoculated with Podosphaera xanthii. The line bars represent the standard errors of the means. Different letters denote significant difference at the $p<0.05$ level by Duncan's new multiple range test $(n=12)$. The treatments are detailed in the footnote of Table 1 

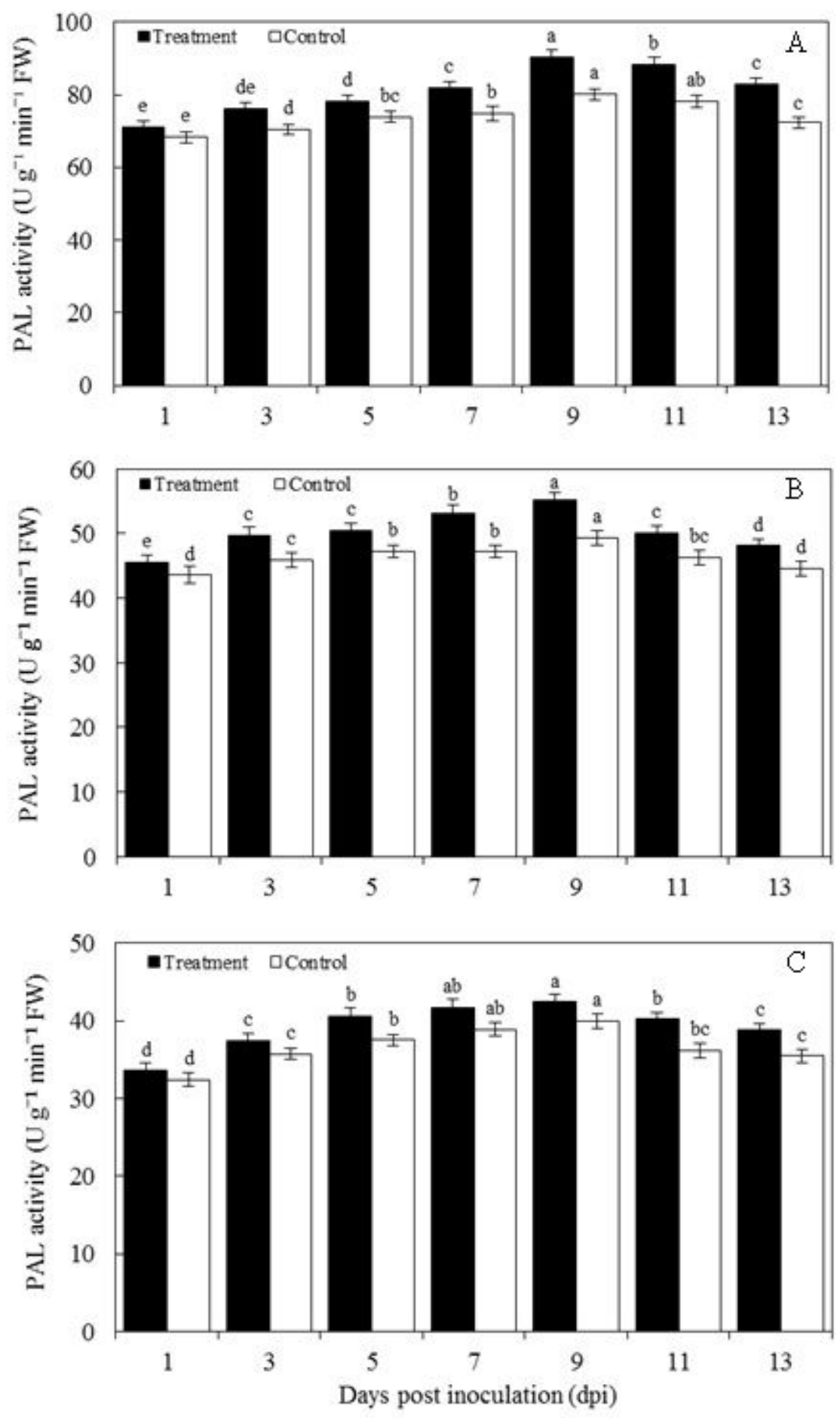

Figure 3

PAL activity in the (A) leaves, (B) petioles, and (C) stems of Jin12 F1 at different time points after inoculated with Podosphaera xanthii. The line bars represent the standard errors of the means. Different letters denote significant difference at the $p<0.05$ level by Duncan's new multiple range test $(n=12)$. The treatments are detailed in the footnote of Table 1 

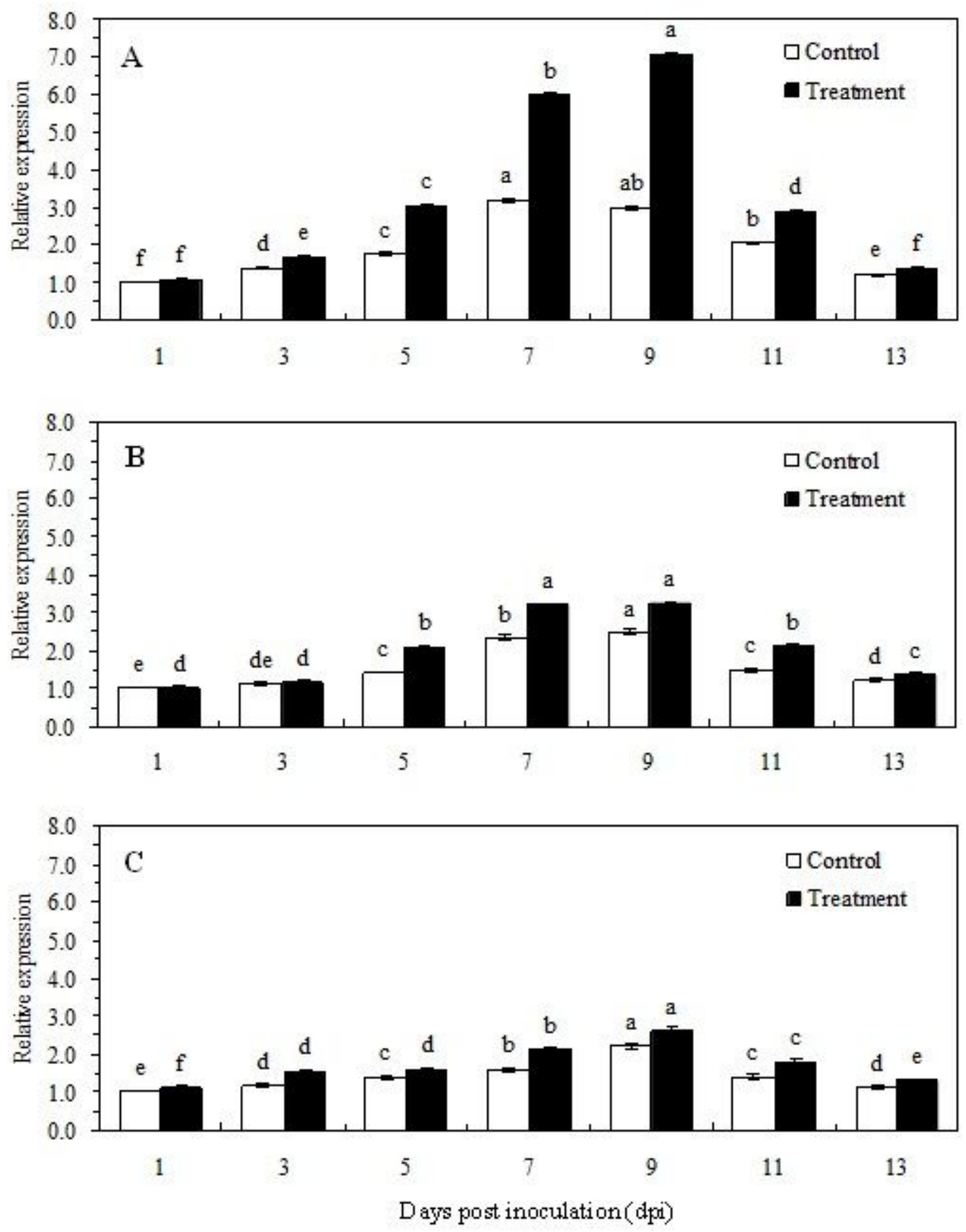

Figure 4

Expression levels of PAL gene in the (A) leaves, (B) petioles, and (C) stems of Sixing F1 at different time points after inoculated with Podosphaera xanthii. The line bars represent the standard errors of the means. Different letters denote significant difference at the $p<0.05$ level by Duncan's new multiple range test $(n=12)$. The treatments are detailed in the footnote of Table 1 

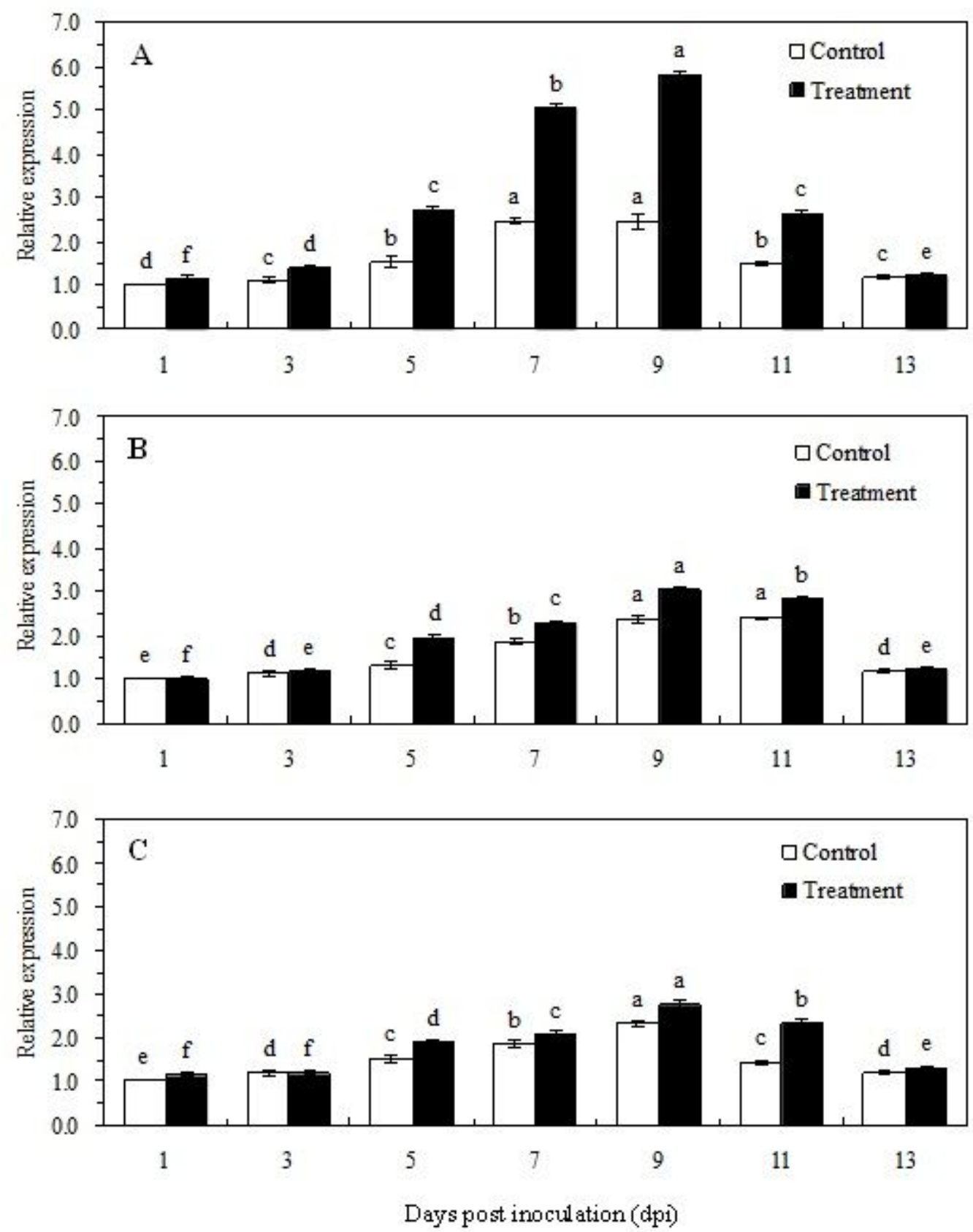

Figure 5

Expression levels of PAL gene in the (A) leaves, (B) petioles, and (C) stems of Jin12 F1 at different time points after inoculated with Podosphaera xanthii. The line bars represent the standard errors of the means. Different letters denote significant difference at the $p<0.05$ level by Duncan's new multiple range test $(n=12)$. The treatments are detailed in the footnote of Table 1 

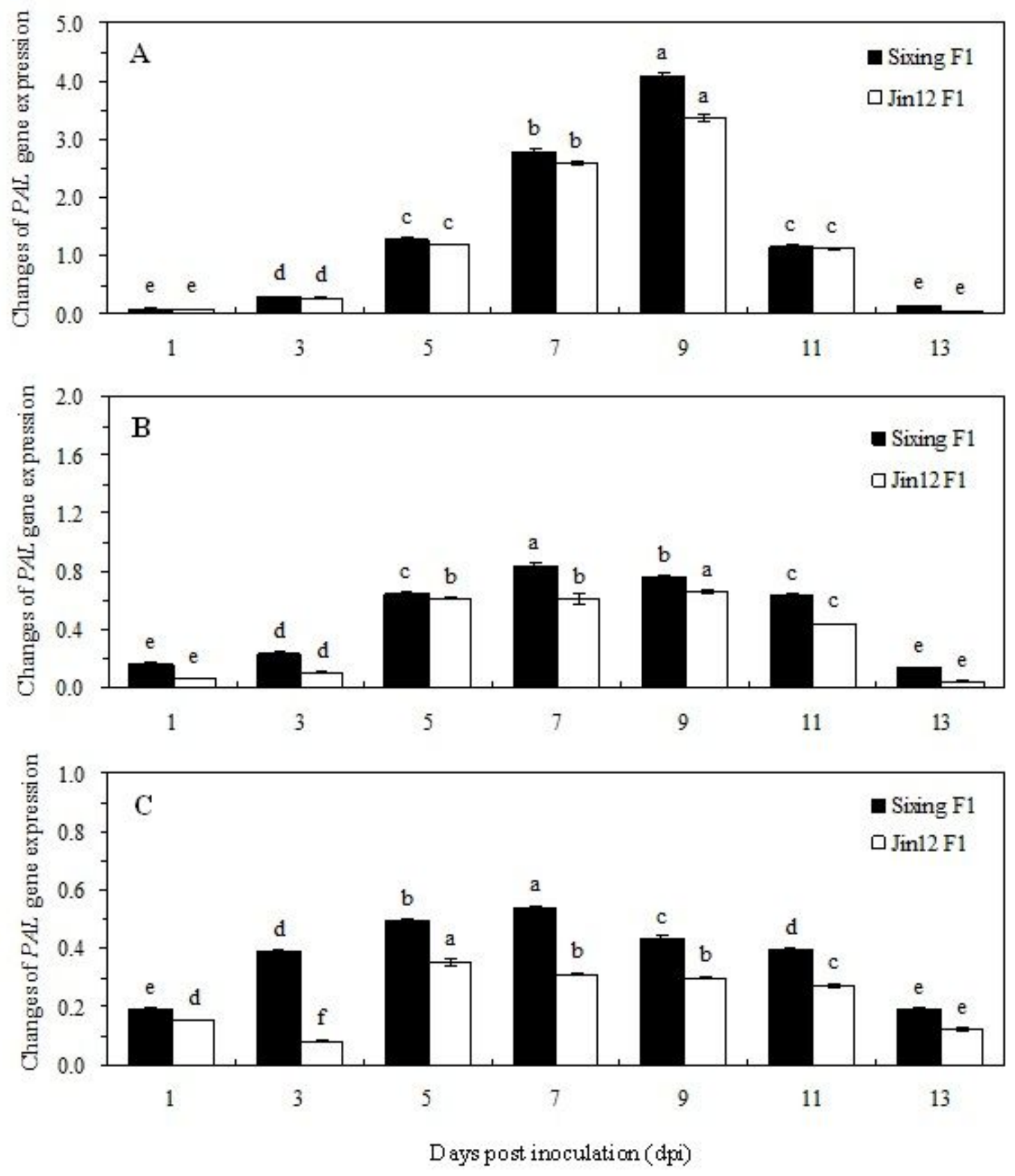

Figure 6

Changes of PAL gene expression in different cultivars and tissues (A) leaves, (B) petioles, and (C) stems of Cucurbita pepo at different time points after inoculated with Podosphaera xanthii. The line bars represent the standard errors of the means. Different letters denote significant difference at the $p<0.05$ level by Duncan's new multiple range test $(n=12)$ 